\title{
ПОГРЕБЕНИЯ ИЗ МОГИЛЬНИКА БЕСИНШИТОБЕ В ОТРАРСКОМ ОАЗИСЕ
}

\author{
(C) 2019 г. А.К. Авизова, Е.А. Есжан, С.Ш. Акылбек
}

\begin{abstract}
В статье публикуются новые материалы из раскопок городища Бесиншитобе в Отрарском оазисе. В основе памятника залегают руины архитектурного сооружения кангюйского времени, в оплыве и завале которого были произведены захоронения усопших. Систематическое изучение его началось в 2015 г. и продолжается по настоящее время. За четыре полевых сезона были выявлены около 50 погребений, 19 из них обнаружены и вскрыты в 2018 г. Все они представлены впускными погребениями в простых ямах без дополнительных конструкций. Проследить форму могильной ямы не всегда удавалось, однако в большинстве случаев она имела узкую продолговатую форму с закругленными углами. По обряду эти погребения различаются. Выделяются погребения без сопроводительного инвентаря, захоронения в глиняных сосудах, помещенных в могильные ямы и погребения с инвентарем. Наиболее ранними являются погребения с сопроводительным инвентарем. Ориентация костяка головой на северо-запад и на северо-запад с небольшим отклонением к северу, а также отсутствие сопроводительного инвентаря позволяет считать захоронения первой группы мусульманскими. Большая часть из этих могил датируется караханидским временем, остальные предварительно относятся к XIII-XV вв.

Ключевые слова: археология, Отрарский оазис, городище, впускные погребения, искусственная деформация черепа, керамика, монета, наконечники стрел, погребения в сосудах
\end{abstract}

\section{Введение}

В 2015 г. археологический отряд Южно-Казахстанского государственного университета им. М. Ауэзова начал раскопки на городище Бесиншитобе [Байпаков, Авизова, 2015, с. $182-$ 214]. Работы первого полевого сезона (траншея I) позволили выявить здесь остатки крупного монументального сооружения начала I тыс. н.э., возведенного на глинобитной платформе. В 2016 и 2017 гг. раскопочные работы велись на верхней площадке бугра (раскопы I и II). Юго-западная стена центрального сооружения прослежена в длину на 2,5 м, северо-западная стена - на более чем 9 м [Байпаков и др., 2016, с. 395-413; Байпаков и др., 2017, с. 17-22]. При вскрытии западного и северо-западного участка центральной части древней постройки были обнаружены 29 разновременных впускных погребений. Все они совершены в ямах, впущенных в руины этого сооружения.

\section{Описание материала}

В 2018 г. работы велись в северозападной части верхней площадки городища. Раскоп размерами $12 \times 13$ м был заложен рядом с раскопом II 2017 г. (рис. 1). Два длинных помещения, обнаруженные на этом участке 
здания, были вскрыты лишь частично (рис. 2). Полы помещений зафиксированы на уровне конца VI яруса (рис. 3). Из завала конструкций и пола получены керамическая курильница и фрагменты лепной керамики. При вскрытии помещений центрального здания обнаружены еще 19 захоронений (рис. 4). Из них 18 зафиксированы на глубине 0,6-1,25 м от поверхности холма, одно - на глубине 2 м.

Самыми многочисленными являются погребения, для которых не характерен сопроводительный инвентарь (15 из 19). Из них шесть принадлежало детям (погребения № 30, 31, $33,34,36,39)$, восемь - взрослым индивидуумам (погребения № 30, 32, 35, $37,40,41,44,45,47)$.
Детские погребения имеют различную степень сохранности. В некоторых могилах отдельные кости смещены или вовсе отсутствуют. Для них характерно вытянутое положение на спине головой на С3. В двух случаях костяк ориентирован головой на СС3. В одном случае череп погребенного ребенка покоился на правой височной кости. В других погребениях - череп на затылке, лицо обращено вверх. В остальных могилах череп представлен отдельными костями. Руки умерших лежали вдоль туловища, иногда руки согнуты в локте, ноги расположены параллельно друг другу. Лишь один из них уложен со слегка согнутой в коленях правой ногой, а кости левой ноги смещены.

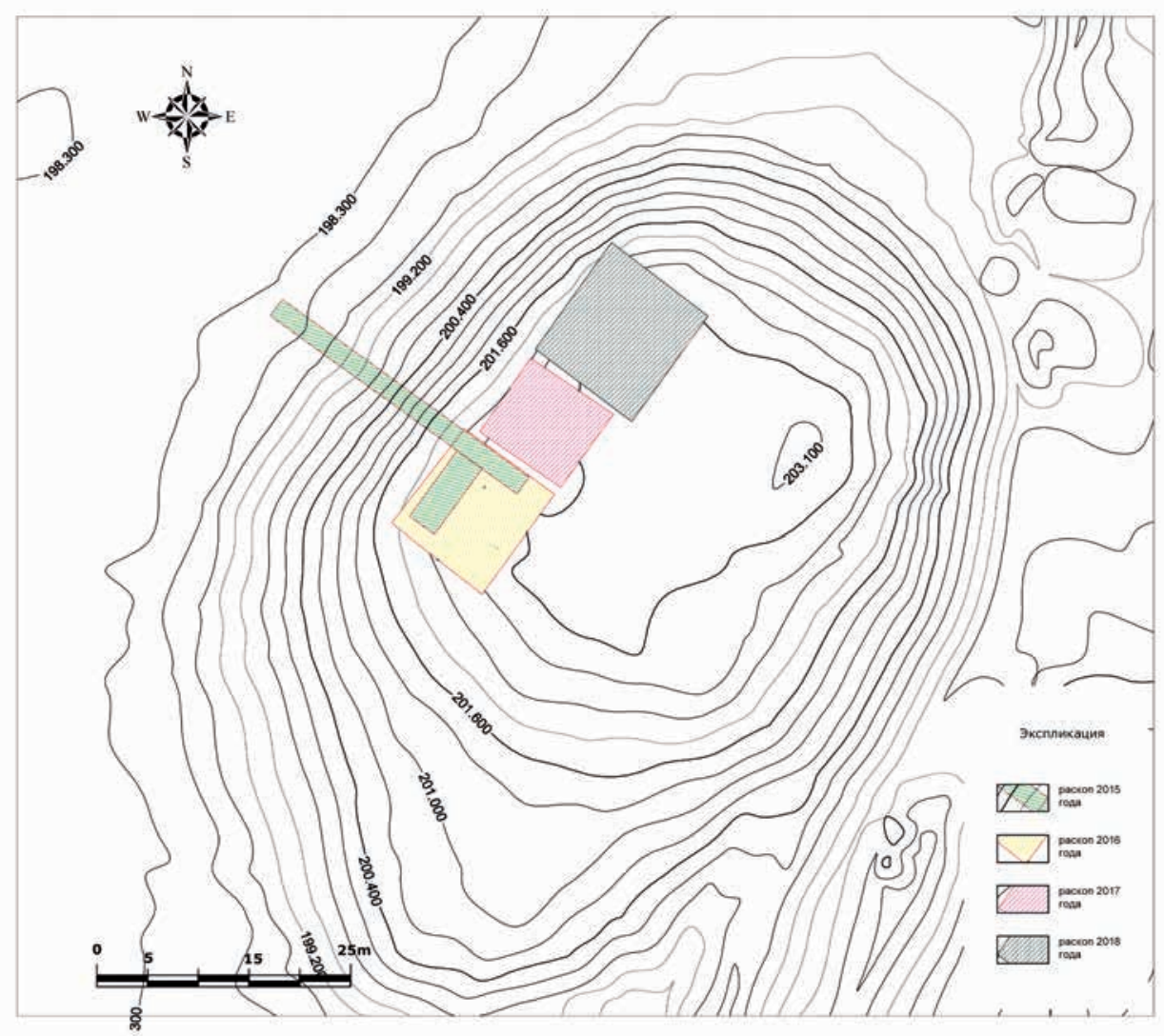

Рис. 1. Контуры раскопов 2015-2018 г2.

Fig. 1. Outline of excavations 2015-2018 
Погребения № 32, 35 и 41 принадлежат взрослым индивидуумам. Для них характерно вытянутое положение на спине головой на СС3.

В погребении № 32 череп уложен на правом виске, повернут лицом к западу. Левая рука согнута в локте под прямым углом, правая рука сложена на груди, ноги расположены параллельно друг другу, кости стоп скрещены (левой ноги лежали на правой).

Череп погребенного № 35 покоился на правом виске лицом к югозападу, левая рука согнута в локте под прямым углом, правая рука вытянута вдоль тела. Ноги расположены параллельно друг другу, кости стоп чуть отведены в сторону. Область грудной клетки (кости лопаток, ребер, позвонков) подвергалась горению. Ритуал неполного трупосожжения с покойником совершался, по-видимому, в другом месте, так как следы огня внутри могилы не зафиксированы.

В погребении № 41 череп лежал на затылке, но чуть повернутый на правый висок, лицом к западу. Левая рука погребенного полусогнута в локте, кисти руки уложены на тазовых костях. Правая рука согнута в локте под прямым углом, кисти руки положены на левое предплечье.

Для следующих трех погребений характерно вытянутое положение на спине головой на северо-запад. У всех череп - на правом виске, повернут лицом к юго-западу. Положение кисти рук погребённых представлено в разнообразных вариантах.

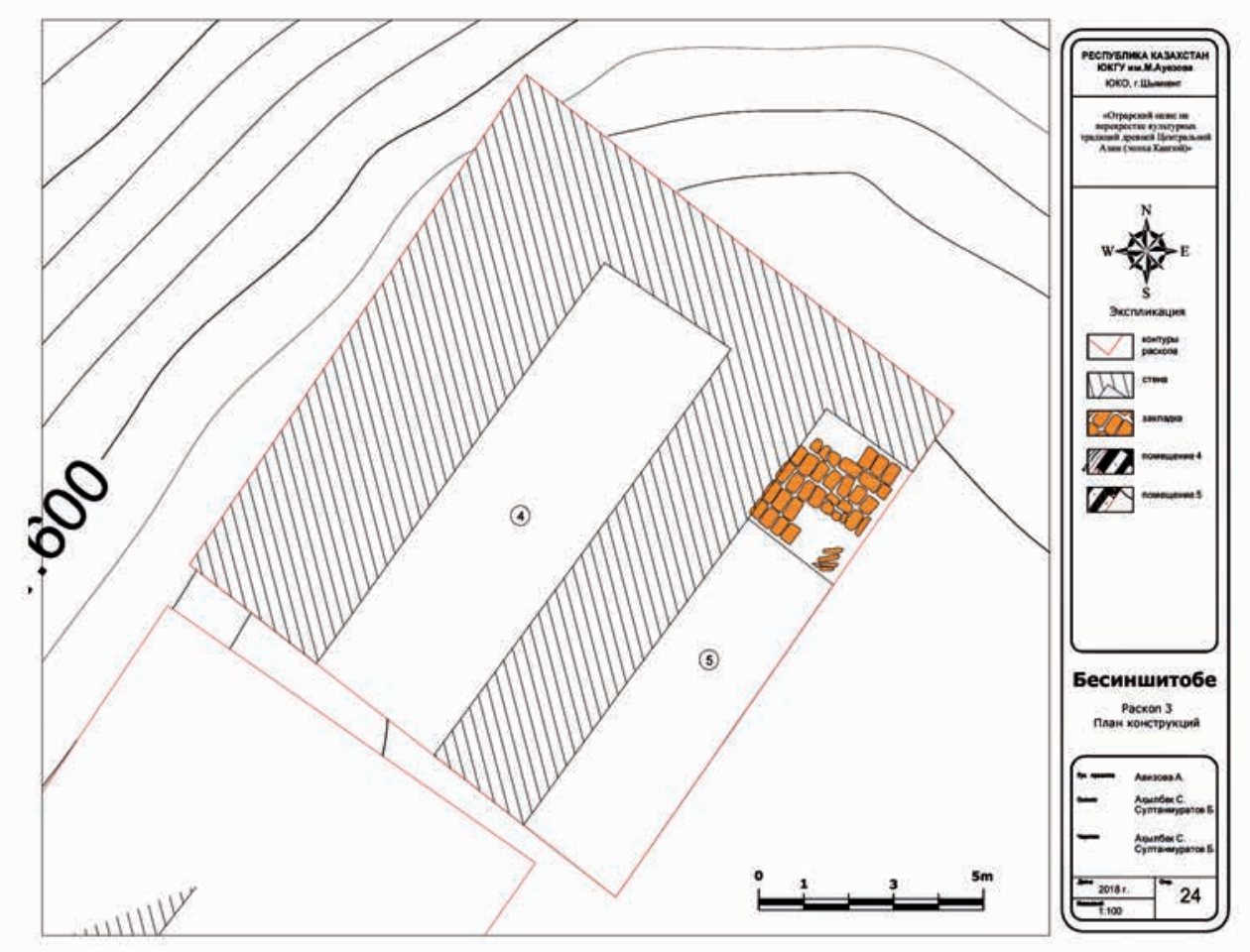

Рис. 2. План раскопа III, 2018 г.

Fig. 2. Excavation Plan for III, 2018 


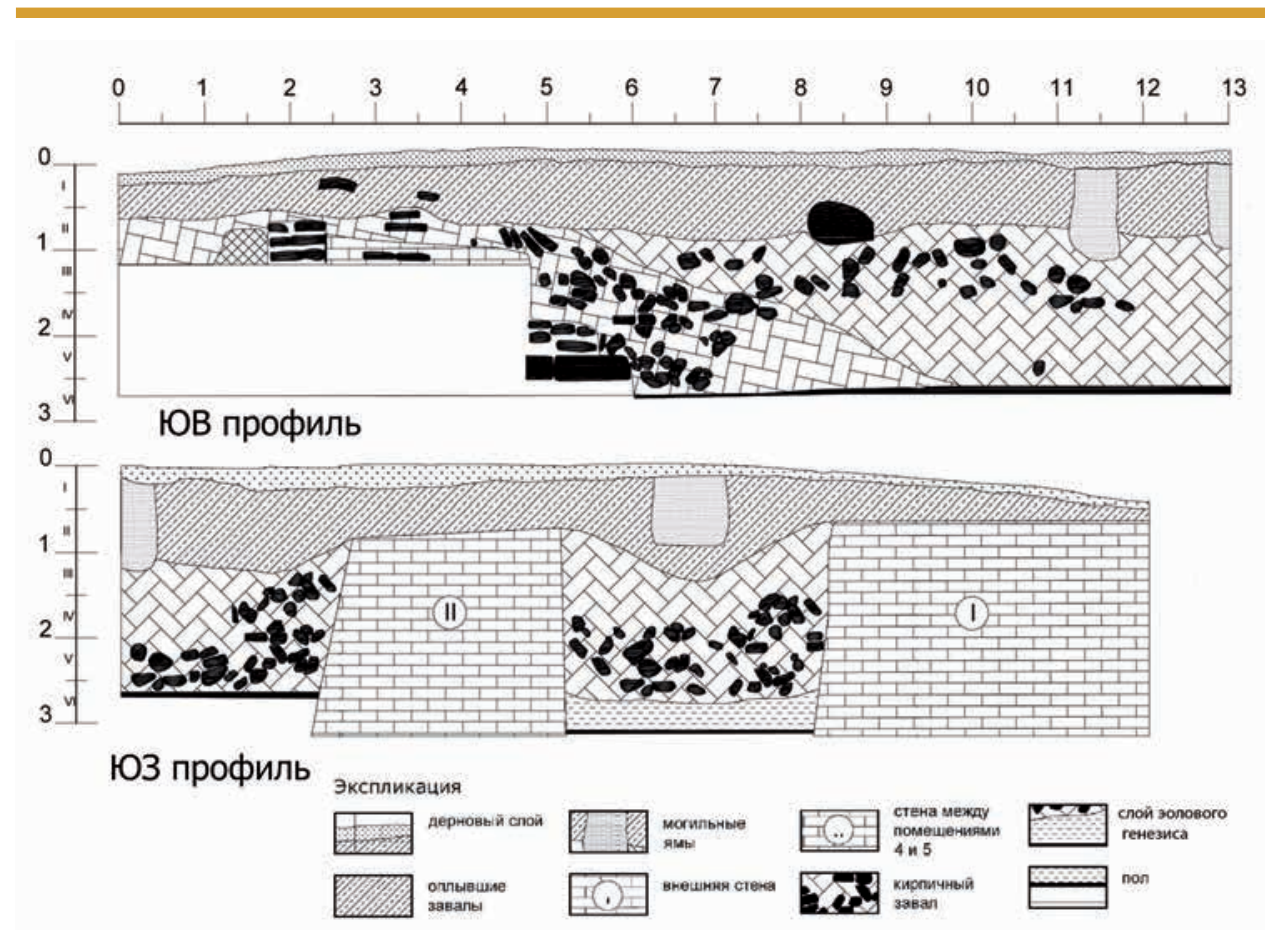

Рис. 3. Профиль раскопа III, 2018 г.

Fig. 3. Profile excavation for III, 2018

В погребении № 37 обе руки покойника полусогнуты в локтях и скрещены (кости правой руки лежали на левой), кости кисти рук лежали на тазовых костях. Ноги расположены параллельно друг другу, кости стоп сведены вместе.

В погребении № 40 руки покойника полусогнуты в локте, кисти рук располагались на тазовых костях. Ноги расположены параллельно друг другу, кости стоп чуть отведены в стороны. Череп костяка № 45 находился на затылке, лицо обращено вверх. Руки согнуты в локтях под прямым углом, кисти рук уложены на животе.

В погребениях № 44 и 47 не представляется возможным определить ориентировку погребенных и установить позу по причине слишком плохой сохранности. Первое оказалось разрушенным, кости перемеша- ны, череп отсутствовал. Во второй могиле обнаружено несколько ребер и череп.

Погребальная яма № 42 расположена над погребением № 47. Прямоугольного очертания могила размерами $2,5 \times 1 \times 0,2$ м, края которой были обложены кладкой из двух рядов жженого кирпича размерами $25 \times 25 \times 5$ см и $27 \times 27 \times 5$ см, оказалась пустой.

Выделяется погребение № 48, совершенное в лежащем на боку хуме горловиной на северо-восток. Сосуд расположен на глубине 1-1,25 м от поверхности холма. У него вытянутое яйцевидное тулово, резко покатые плечики, диаметр небольшого плоского дна чуть меньше диаметра венчика (рис. 6, 16). Высота около $80 \mathrm{~cm}$, диаметр тулова равен $58 \mathrm{~cm}$, диаметр венчика и дна 32-30 см. Отогнутый наружу высокий прямой вен- 


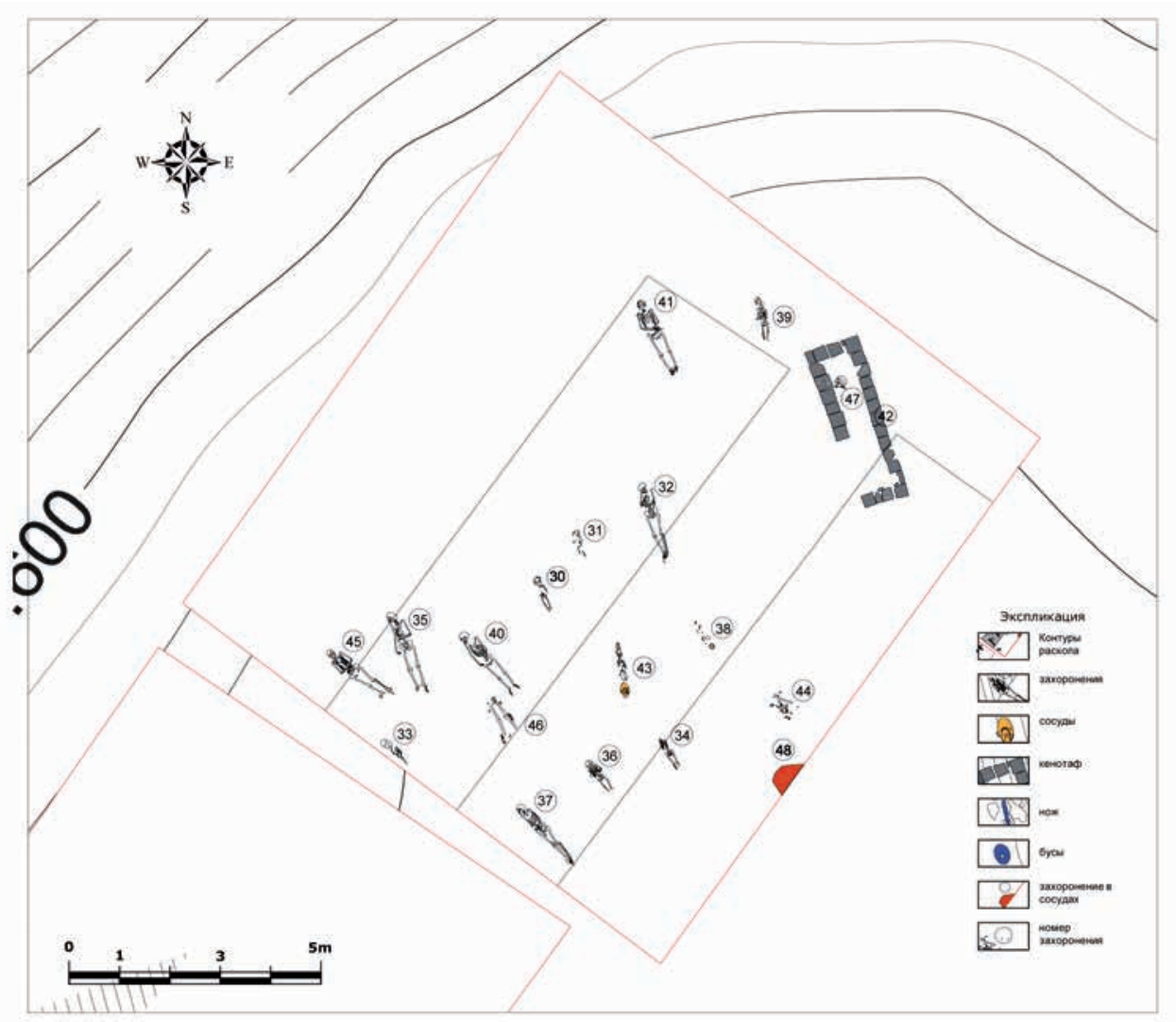

Рис. 4. План раскопа III, погребения

Fig. 4. Excavation Plan for III, burial

чик (h - 4,5 см) подрямоугольный в сечении с относительно плоским бережком посажен в узкую горловину. Венчик снаружи орнаментирован двумя рядами наклонных пальцевых вдавлений. Сосуд изготовлен ручной лепкой, с наружной стороны покрыт целиком, а внутри - лишь по горлу светлым ангобом, тщательно заглажен. Поверх ангоба густой краснокоричневой краской нанесены потеки, идущие от горловины вниз до дна. Дно имеет отпечатки ткани. Аналогичные хумы достаточно широко представлены в керамических комплексах Средней Сырдарьи VII-VIII вв., таких как, например, на городище Отрар [Акишев и др., 1972, с. 89-90, рис. 43,$1 ; 44$,
1, 2], Ботайтобе [Акишев и др., 1972, c. 145, рис. 110], Жамантобе [Акишев и др., 1972, с. 152, рис. 120], КуюкМардан [Авизова, 2014, с. 202-221], в верхнем строительном горизонте городища Сидак [Смагулов, Яценко, 2014, с. 275-281, pис. 4, 2-3].

В хуме выявлено детское коллективное захоронение с нарушенным анатомическим порядком костей. Кости в целом имеют хорошую сохранность, принадлежат девяти младенцам примерно одинакового возраста. В заполнении при расчистке был найден амулет из раковины с отверстием. Других находок не было.

В следующую группу входят три захоронения с сопроводительным инвентарем. 
В погребении № 38 обнаружен неполный скелет ребенка (рис. 5). Кости черепной коробки найдены по отдельности. Смещение и отсутствие некоторых костей не позволяет определить положение рук и ног покойника. Однако заметно, что ребенок уложен в вытянутом положении на спине головой на юго-восток. В области живота найдена крупная бусина из стеклопасты (рис. 6, 1). Около головы сверху положена красноглиняная кружка из плотного светло-коричневого теста (рис. 6, 4). Сосуд имеет округлое приземистое тулово, вытянутую горловину, переходящую в прямую слегка отогнутую наружу закраину. Поверхность сосуда покрыта красным ангобом и лощена. Высота кружки 8 см, диаметр венчика 6,5 см, диаметр тулова 9 см, диаметр донца 6 см.

Погребение № 43 совершено в вытянутом положении на спине головой на юг. Костяк принадлежит ребенку. Череп на затылке, лицо обращено вверх. Череп удлиненный, очень высокий, со следами искусственной деформации. Локтевые кости не сохранились, ноги вытянуты параллельно друг другу. На тазовых костях расчищен небольшой железный нож (рис. 6, 10). Слева от головы найдена крупная бусина (рис. 6, 2). За черепом стоял красноглиняный кувшин с вертикальной ручкой и цилиндрическим носиком (рис. 6, 6). Высота сосуда составила 25 см, диаметр венчика $8 \mathrm{~cm}$, диаметр тулова 16,5 см, диаметр донца 9 см. На устье кувшина была положена небольшая красноглиняная чаша с высокой отогнутой наружу закраиной (рис. 6, 5). Высота чаши 6 см, диаметр венчика 8,5 см, диаметр донца 4,5 см.

Погребение № 46 обнаружено при расчистке юго-восточной стены помещения № 4 на глубине 2 м. Моги- ла ориентирована по линии С3-ЮВ. Северо-западная половина могильной ямы была вырыта в завале помещения, а юго-восточная половина ее врезана в стену помещения. Костяк взрослого человека был уложен в вытянутом положении на спине головой на юго-восток. Череп - на затылке, руки - вдоль туловища, ноги параллельны друг другу. Череп плохой сохранности, основание его разрушено, остальные кости, в целом, хорошо сохранились. Область грудной клетки погребенного подвергалась воздействию огня (лопатки, ребра, отдельные позвонки).

Погребенного сопровождал комплекс железных предметов. Над правым плечом и в области живота расчищены фрагменты железных удил с псалиями (рис. 6, 15). Слева от таза лежал нож средних размеров: длина лезвия $15 \mathrm{~cm}$, черенок - около 4-5 cм (рис. 6, 12). В области пояса под тазовыми костями обнаружены - маленький нож, П-образный стержень, пластина и крючок (рис. $6,11,13,14$ ). Под правой кистью погребенного лежали железные черешковые трехперые наконечники стрел с ромбовидной головкой. Длина наконечников 7,5-8 см. Головки ромбической формы, длина - 4 см, высота пера около 1 см. Длина черешка 3,5-4 см (рис. 6, 8, 9).

Аналогичныенаконечникистрел известны в материалах погребальных комплексов Средней Азии, Поволжья, Приуралья, Южной Сибири и других регионов с начала I тыс. н.э. [Кожомбердиев, Худяков, 1987 , с. 81 , рис. 3 , 4; Литвинский, 1965, с. 75-91; 1968, с. 102 , рис. 8 ; Сорокин, 1956; Худяков, 1986, рис. 3-6]. Железные черешковые трехперые наконечники стрел с ромбовидной головкой наибольшее распространение получают в IV-V вв. и доживают до VII-VIII вв. [Хазанов, 


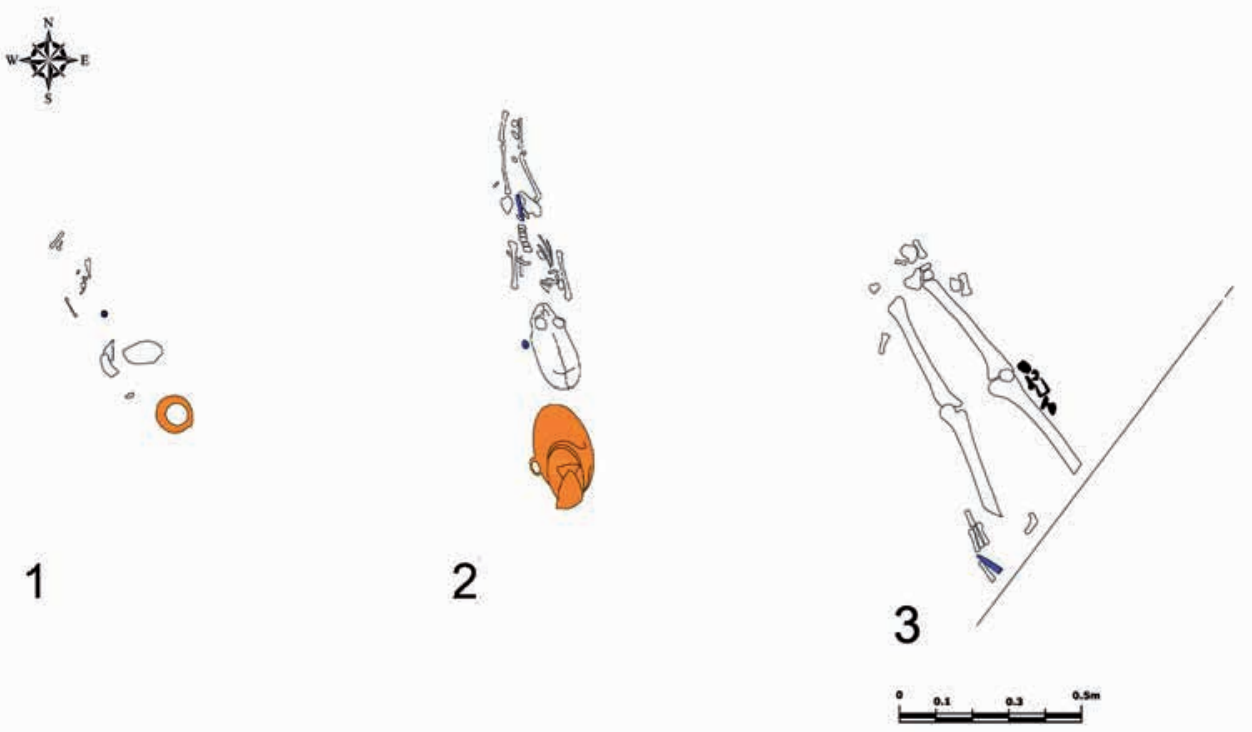

Рис. 5. Ориентация и ритуальная поза погребенных. 1 - погребение № 38; 2 - погребение № 43; 3 - погребение № 46

Fig. 5. Orientation and ritual posture of deceased. 1 - burial no. 38; 2 - burial no. 43; 3 - burial no. 46

1971, с. 40-41, табл. ХІХ, 29-31, 36; табл. XXII, 10, 11]. Наконечники этого типа встречаются также в погребениях Конуртобе 1, Борижар, Сидак [Байпаков и др., 2005, с. 18, 22, 28, рис. 1, 16; фото 3, 8], Актобе 2 [Максимова и др., 1968, с. 75-76, рис. 32], Кызылкайнар-тобе [Мерщиев, 1970, с. 79-92, рис. 32] и датируются IV-V вв.

В ходе вскрытия верхних слоев раскопа (I - начало II яруса) обнаружены многочисленные фрагменты крупной тарной посуды. Всего было шесть фрагментов венчиков и семь крупных обломков донцевых частей, остальные - стенки. Сосуды встречались отдельными фрагментами, иногда - скоплениями крупных обломков. Возможно, они являются остатками разрушенных погребений в сосудах при устройстве более поздних могил. Судя по количеству обломков сосудов, этот участок холма в более раннем периоде могли занимать захоронения в хумах.
По форме хумы и хумчи представлены несколькими разновидностями. Имеется фрагмент лепного хума с шаровидным туловом. Отогнутый наружу подквадратный в сечении венчик отделен от плечика неглубокой ложбиной. Диаметр венчика 44 см. Сосуд изготовлен из сероватой глины с примесью песка и дресвы, обжиг хороший. Поверхность покрыта светло-красным ангобом, украшена потеками более темной краски. Есть фрагменты хумов, аналогичных сосуду из погребения № 48. Диаметр венчика 28-32 см.

Отличительным признаком большинства хумов являются отпечатки ткани на днищах. Широкие, плоские, не совсем ровные донца сосудов имеют диаметр от 30 до 42 см (рис. 7 , 8). Есть экземпляры, формованные на песчаной подсыпке.

Имеются обломки тонкостенной корчаги, изготовленной ручным 


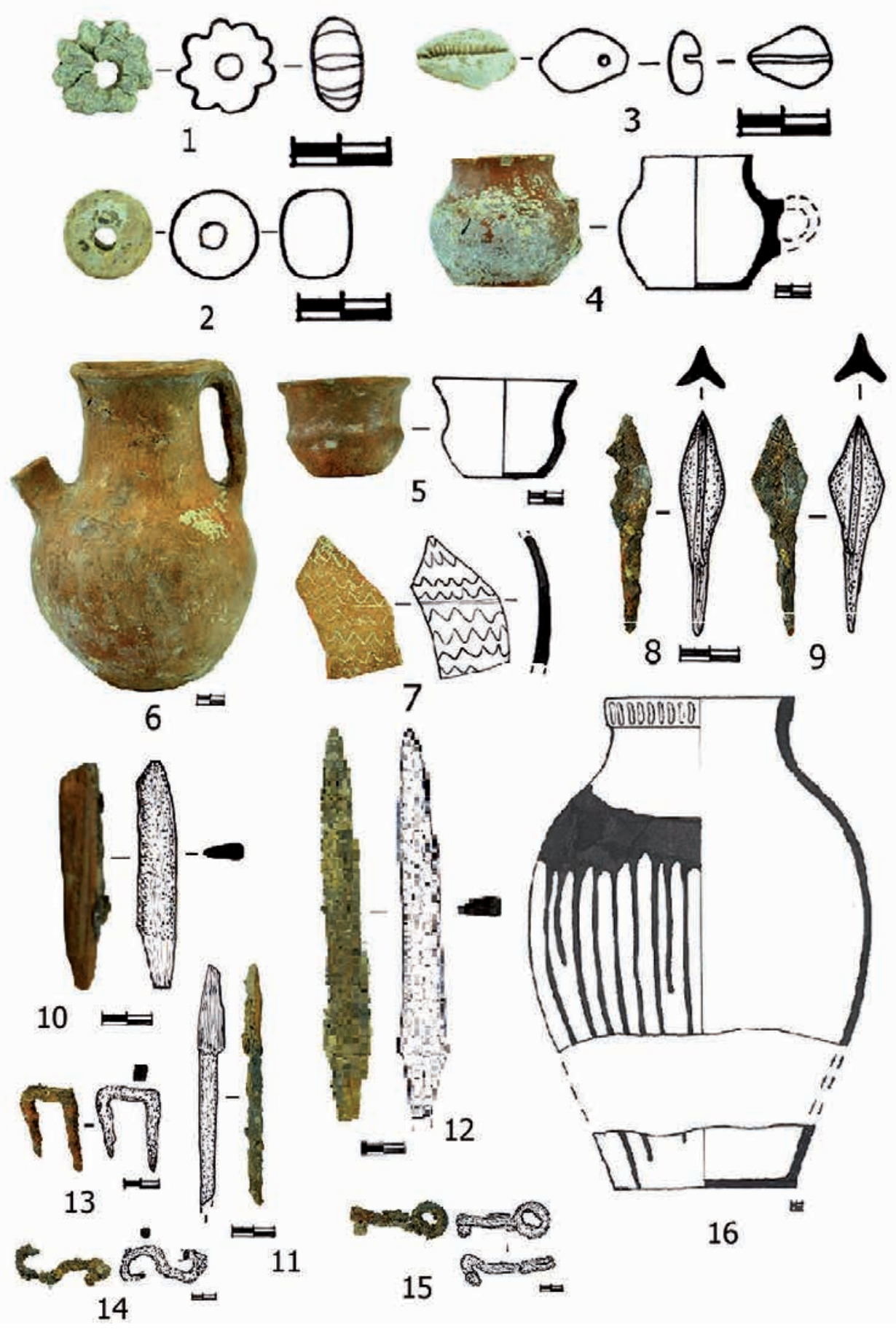

Рис. 6. Находки из погребений

Fig. 6. Finds from burials 

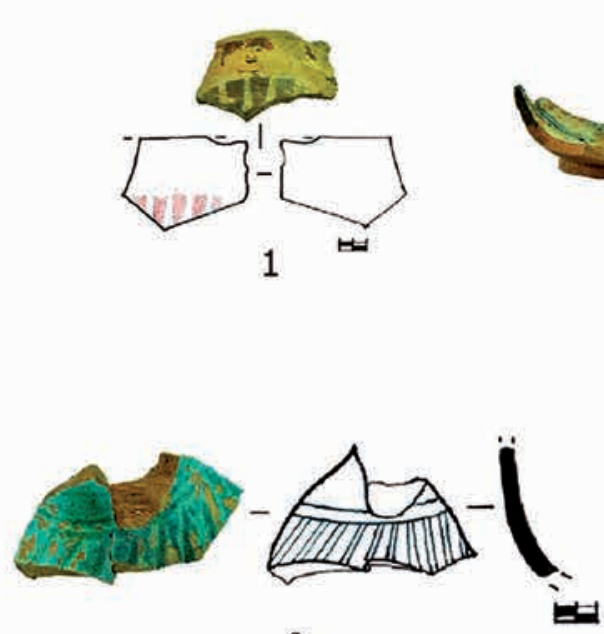

3
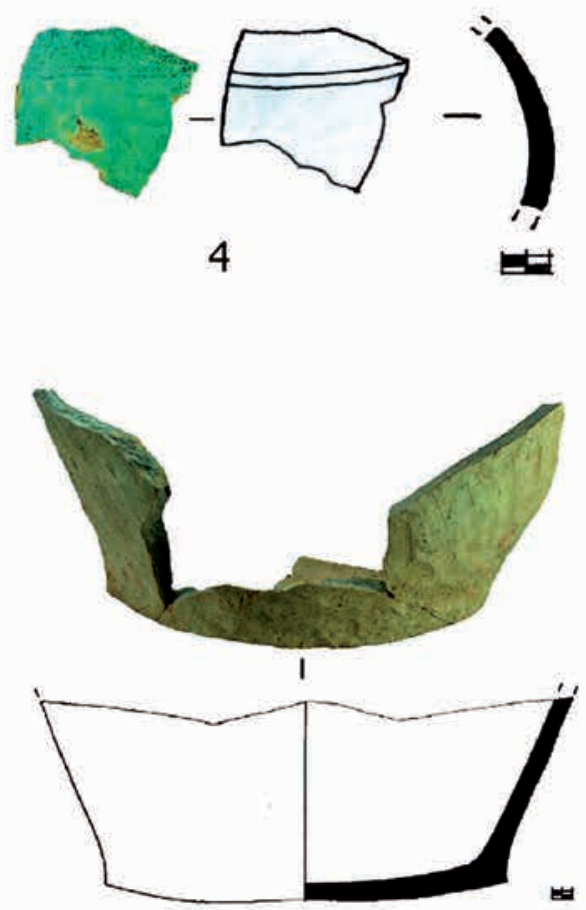

8
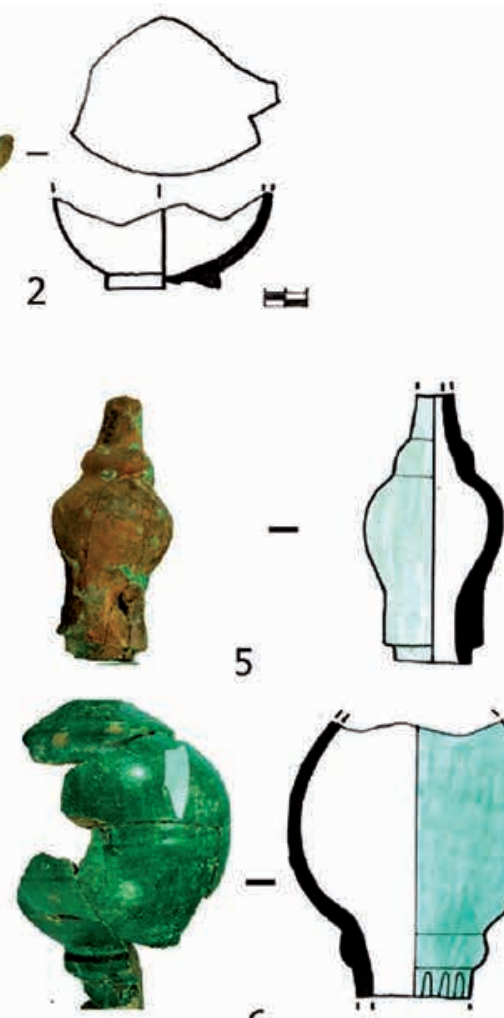

6
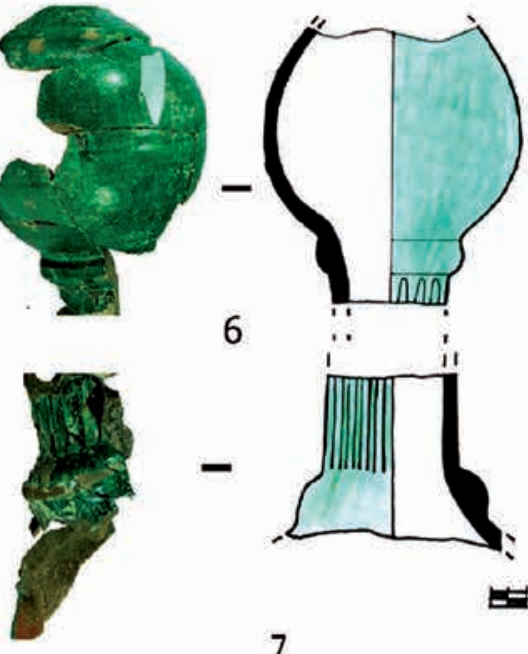

7

Рис. 7. Находки из верхнего горизонта бугра

Fig. 7. Finds from the upper horizon of the hill

способом из хорошо отмученной глины. Черепок в изломе кирпичнокрасного цвета. Поверхность сосуда с обеих сторон покрыта темно-красным ангобом. Плечики украшены прочерченным волнистым орнаментом (рис. 6, 7). Плечики другой хумчи украшены прочерченным ромбовидным орнаментом, нанесенным широкой мягкой палочкой по сырой глине. Поверхность сосуда покрыта серым ангобом и лощена. 
Помимо описанных выше сосудов можно отметить несколько обломков кувшинов, фрагменты глазурованной посуды и бронзовую монету раннетюркского времени, найденные при снятии верхних слоев уровня I-II ярусов (рис. 7, 1-7).

Вся посуда из верхних слоев, за исключением хумов и хумчи, изготовлена на гончарном круге. Глазурованная посуда представлена в основном мелкими обломками стенок, придонных частей блюд и чаш. Среди них выделяются фрагменты горшка со сферическим туловом, покрытого голубой не прозрачной поташевой глазурью. Плечики одного украшены наклонными линиями, второго - горизонтальными. Встречаются фрагменты блюд, покрытых плотной непрозрачной коричневой и зеленой поливой. Из-за повышенной засоленности поверхности холма Бесиншитобе у некоторых фрагментов сохранились лишь участки глазури. К этой же группе относятся куббы детали от купола мечети, покрытые плотной непрозрачной зеленой глазурью снаружи.

\section{Обсуждение}

По характеру погребального обряда все захоронения разделяются на три группы. Первую из них образуют безынвентарные погребения. Во всех могилах встречены одиночные захоронения. Все умершие положены непосредственно на дно могилы. Важной отличительной особенностью погребений без сопроводительного инвентаря является ориентировка головы погребенного на северо-запад и на северо-запад с небольшим отклонением к северу. Особняком в этой группе стоит захоронение № 42, края могильной ямы которого оформлены кирпичной кладкой. Выделяются также могильные ямы, перекрытые клад- кой из сырцового кирпича. В одном из погребений зафиксировано неполное сожжение умершего. Наиболее ранние погребения этого комплекса относятся к IX-XII вв.

Вторая небольшая группа включает погребения в крупных глиняных сосудах, помещенных в ямы. Всего обнаружено три захоронения. Все они детские, одно из которых коллективное. В одном из сосудов вместе с погребенным находилась бронзовая монета, в другом - амулет-раковина. На основании аналогий данную группу можно отнести к VII-VIII вв.

Третья группа объединяет одиночные захоронения с сопроводительным инвентарем. Наблюдаются различные вариации в ориентации головы: северная, северо-западная, северо-восточная, юго-восточная, юго-западная. Присутствуют случаи искусственной деформации черепа и ритуал неполного трупосожжения. Для всех могил характерен довольно скудный сопроводительный инвентарь: один-два сосуда, изредка железный нож, из предметов украшения - единичные бусы. Оружие имелось в двух погребениях, идол - в одном. Наиболее ранние погребения данной группы на Бесиншитобе относятся к IV-V вв.

\section{Выводы}

Таким образом, погребальные сооружения могильника Бесиншитобе представлены однотипными простыми могильными ямами, в которые помещались погребения, и погребения в глиняных сосудах. По характеру погребальных обрядов их можно разделить на три группы: безынвентарные погребения IX-XII и XIII-XV вв., захоронения в глиняных сосудах VII-VIII вв. и погребения с сопроводительным инвентарем IV-V вв. 


\section{ЛИТЕРАТУРА}

1. Авизова А.К. Исследования городища Куюк-Мардан на юге Казахстана // Вопросы истории Кыргызстана. 2014. № 3-4 (31). С. 202-221.

2. Акишев К.А., Байпаков К.М., Ерзакович Л.Б. Древний Отрар (топография, стратиграфия, перспективы). Алма-Ата: «Наука», 1972. 215 с.

3. Байпаков К.М., Авизова А.К. Раскопки городищ Пшакшитобе и Бесиншитобе в Отрарском оазисе // Известия НАН РК. Сер. обществ. и гум. наук. 2015. № 6. C. $182-214$.

4. Байпаков К.М., Авизова А.К., Есжан Е.А., Акылбек С.Ш. Раскопки городища Пшакшитобе эпохи Кангюй // Актуальные проблемы археологии Евразии: сб. матер. междунар. научн. конф., посвящ. 25-летию независимости Республики Казахстан и 25-летию Института археологии им. А.Х. Маргулана. Алматы: Институт археологии им. А.Х. Маргулана, 2016. С. 395-413.

5. Байпаков К.М., Смагулов Е.А., Ержигитова А.А. Раннесредневековые некрополи Южного Казахстана. Алматы: «Баур», 2005. 224 с.

6. Кожомбердиев И.К., Худяков Ю.С. Комплекс вооружения кенкольского воина // Военное дело древнего населения Северной Азии. Новосибирск: «Наука», 1987. C. 81-84.

7. Литвинский Б.А. Среднеазиатские железные наконечники стрел // СА. 1965. № 2. С. 75-91.

8. Максимова А.Г., Мерщиев М.С., Вайнберг Б.И., Левина Л.М. Древности Чардары (археологические исследования в зоне Чардаринского водохранилища). АлмаАта: «Наука», 1968. 263 с.

9. Мерщиев М.С. Поселение Кзыл-Кайнар-тобе I-IV веков и захоронение на нём воина IV-V века // По следам древних культур Казахстана. Алма-Ата: «Наука», 1970. C. $79-92$.

10. Смагулов Е.А., Яценко С.А. Новые находки серий доисламских знаков/тамга/ нишан в Туркестанском оазисе (городища Культобе и Сидак): связь с кочевым миром // Проблемы изучения нематериального культурного наследия народов Казахстана и Центральной Азии: топонимика, эпиграфика, искусство: сб. матер. междунар. научн. конф. Алматы: EVO PRESS, 2014. С. 275-281.

11. Сорокин С.С. О датировке и толковании Кенкольского могильника // КСИИМК. 1956. Вып. 64. С. 3-14.

12. Хазанов А.М. Очерки военного дела сарматов. М.: «Наука», 1971. 169 с.

13. Худяков Ю.С. Вооружение средневековых кочевников Южной Сибири и Центральной Азии. Новосибирск: «Наука», 1986. 268 с.

\section{Сведения об авторах:}

Авизова Айман Карайдаровна - кандидат исторических наук, доцент, ЮжноКазахстанский государственный университет им. М. Ауэзова (г. Шымкент, Казахстан); aimanavizova@mail.ru

Есжан Ержан Ауелханулы - научный консультант, ТОО «Archeo-service» (Шаульдер, Казахстан); erjan7070@mail.ru

Акылбек Серик Шаймерденулы - заместитель директора по научной работе, Отрарский государственный археологический заповедник-музей (Шаульдер, Казахстан); s_akylbek@mail.ru 


\section{ОТЫРАР АЛҚАБЫНДАҒЫ БЕСІНШІТӨБЕ ҚОРЫМЫНЫН ЖЕРЛЕУ ҚАБІРЛЕРІ}

\section{А.К. Авизова, Е.А. Есжан, С.Ш. Ақылбек}

Мақалада Отырар алқабындағы Бесіншітөбе қалашығындағы қазбалардан алынған жаңа материалдар жарияланып отыр. Ескерткіштің негізінде кангюй дәуірінің сәулеттік ғимараты жатыр. Құрылыс қирандылары мен шөгінділерінде адамдардың мүрделері жерленген. Жүйелі зерттеулер 2015 ж. басталып, олар қазірге дейін жалғасуда. Осы уақыт аралығында 50-ге жақын қабірлер ашып зерттелген, соның ішінде 19 қабір 2018 ж. далалық маусымында табылған. Олардың барлығы ежелгі ғимарат қирандысының үстінен қазылған қосымша құрылыссыз қарапайым молалар түріндегі қабірлер болып табылады. Мола шұңқырларының пішінін барлық жағдайда анықтау мүмкіндігі болмады, алайда көпшілік жағдайда ол бұрыштары дөңгеленген ұзыншақ пішінге ие болған. Жерлеу дәстүрі бойынша бұл қабірлер әртүрлі. Жерлеу бұйымдары жоқ қабірлер, молаларға қойылған қыш ыдыстарына салып көму және жерлеу бұйымдарымен қоса жерлеу салт-дәстүрлері кездеседі. Олардың арасында ең ерте қабірлер жерлеу бұйымдарымен қоса жерленгендері болып табылады. Мүрденің басымен солтүстік-батысқа бағытталуы және солтүстік-батыстан солтүстікке қарай ауытқып бағытталуы, сондай-ақ жерлеу бұйымдарының болмауы бірінші топты мұсылмандық қабірлер деп санауға мүмкіндік береді. Осы зираттардың басым бөлігі Қарахан заманында, қалғандары шамамен XIII-XV ғғ. жатады.

Түйін сөздер: археология, Отырар алқабы, қалажұрт, мәдени қабаттағы қабірлер, бас сүйегінің жасанды деформациясы, қыш, теңге, жебенің ұштары, ыдыстағы жерлеу

\section{BURIALS FROM BESINSHITOBE IN THE OTRAR OASIS}

\section{A.K. Avizova, Y.A. Yeszhan, S.Sh. Akylbek}

The article publishes new materials from the excavations of hillfort Besinshitobe in the Otrar oasis. At the base of the monument lie the ruins of the architectural structure of the Kangyu epoch. These burials were made in the ruins of buildings. Its systematic study began in 2015 and continues to the present. During this time, about 50 burials were discovered here, 19 of them were discovered and opened in the 2018 field season. All of them are represented by inlet burials in simple pits without additional structures. It was not always possible to trace the shape of the grave pit, but in most cases it had a narrow oblong shape with rounded corners. According to the rite, these burials differ. Burials without accompanying inventory, burial in earthen vessels placed in grave pits and burials with inventory are distinguished. The earliest are burials with accompanying inventory. Orientation of the backbone head to the north-west and north-west with a slight deviation to the north, as well as the lack of accompanying equipment allows us to consider the burial of the first group as Muslim. Most of these graves date from the Karakhanid epoch, the rest are preliminary to the 9th-12th centuries A.D.

Keywords: archaeology, Otrar oasis, hillfort, inlet burials, artificial skull deformation, ceramics, coin, arrowheads, burials in vessels

\section{REFERENCES}

1. Avizova, A. K. 2014. In Voprosy istorii Kyrgyzstana (Questions of the history of Kyrgyzstan), 3-4 (31), 202-221 (in Russian).

2. Akishev, K. A., Baipakov, K. M. Erzakovich, L. B. 1972. Drevnii Otrar (topografiia, stratigrafiia, perspektivy) (Ancient Otrar (topography, stratigraphy, perspectives)). AlmaAta: "Nauka" Publ. (in Russian). 
3. Baipakov, K. M., Avizova, A. K. 2015. In Izvestiia Natsionalnoi Akademii nauk Respubliki Kazakhstan (Bulletin of the National Academy of Sciences of the Republic of Kazakhstan), 6, 182-214 (in Russian).

4. Baipakov, K. M., Avizova, A. K., Eszhan, E. A., Akylbek, S. Sh. 2016. In Aktualnye problemy arheologii Evrazii (Actual problems of archeology of Eurasia). Almaty: A.Kh. Margulan Institute of Archaeology, 395-413 (in Russian).

5. Baipakov, K. M., Smagulov, Ye. A., Erzhigitova, A. A. 2005. Rannesrednevekovyye nekropoli Yuzhnogo Kazakhstana (Early medieval necropolis of South Kazakhstan). Almaty: "Baur" Publ. (in Russian).

6. Kozhomberdiev, I. K., Hudyakov, Ju. S. 1987. In Voennoe delo drevnego naseleniya Severnoi Azii (Military affairs of the ancient population of Northern Asia). Novosibirsk: "Nauka", 81-84 (in Russian).

7. Litvinskii, B. A. 1965. In Sovetskaya arkheologiya (Soviet Archaeology), 2, 75-91 (in Russian).

8. Maksimova, A. G., Mershchiev, M.S., Vainberg, B. I., Levina, L. M. 1968. Drevnosti Chardary (Antiquities of Chardara). Alma-Ata: "Nauka" Publ. (in Russian).

9. Mershchiyev, M. S. 1970. In Kadyrbayev, M. K. (ed.) Po sledam drevnikh kultur Kazakhstana (In the footsteps of the ancient cultures of Kazakhstan). Alma-Ata: "Nauka", 79-92 (in Russian).

10. Smagulov, E. A. 2013. In Povolzhskaya arkheologiya (The Volga River Region Archaeology), 1 (3), 197-215 (in Russian).

11. Smagulov, E. A., Yatsenko, S. A. 2014. In Problemy izucheniya nematerialnogo kulturnogo naslediya narodov Kazahstana i Centralnoi Azii (Problems of studying the intangible cultural heritage of the peoples of Kazakhstan and Central Asia). Almaty: "EVO PRESS", 275-281 (in Russian).

12. Khazanov, A. M. 1971. Ocherki voennogo dela sarmatov (Sketches of military affairs of the Sarmatians). Moscow: "Nauka" Publ. (in Russian).

13. Khudyakov, Ju. S. 1986. Vooruzhenie srednevekovyh kochevnikov Juzhnoi Sibiri $i$ Tsentralnoj Azii (Armament of medieval nomads of Southern Siberia and Central Asia). Novosibirsk: "Nauka" Publ. (in Russian).

\section{About the Authors:}

Avizova Aiman K. Candidate of Historical Sciences, Associate Professor, M. Auezov South Kazakhstan State University, Shymkent, Republic of Kazakhstan; aimanavizova@mail.ru

Yeszhan Yerzhan A. Candidate of Historical Sciences, Scientific consultant, Archeoservice LLP, Shaulder, Kazakhstan; erjan7070@mail.ru

Akylbek Serik Sh. Deputy Director, Otrar state Archaeologial museum-reservation, Shaulder, Kazakhstan; s_akylbek@mail.ru

\footnotetext{
Мүдделер қақтығысы туралы ақпаратты ашу. Авторлар мүдделер қақтығысының жоқтығын мәлімдейді. / Раскрытие информации о конфликте интересов. Авторы заявляют об отсутствии конфликта интересов. / Disclosure of conflict of interest information. The authors claims no conflict of interest.

Мақала туралы ақпарат / Информация о статье / Information about the article. Редакцияға түсті / Поступила в редакцию / Entered the editorial office: 07.05.2019. Рецензенттер мақұлдаған / Одобрено рецензентами / Approved by reviewers: 14.05.2019. Жариялауға қабылданды / Принята к публикации / Accepted for publication: 21.05.2019.
} 